\title{
PENGUATAN TATA KELOLA PERUSAHAAN MELALUI SIMPLE BOOKEEPING
}

\author{
Jumaiyah $^{1}$, Subadriyah ${ }^{2}$ \\ Program Studi Akuntansi, Universitas Islam Nahdlatul Ulama Jepara \\ Email: jumaiyaha@gmail.com
}

\begin{abstract}
Abstrack
Program pengabdian ini dilaksanakan pada Sentra Ukir Mebel "ToiFur" alamat mitra di Desa Ngebong Rt 21 Rw 7 Mantingan Kabupaten Jepara. Kegiatan ini akan dilakukan selama 6 Bulan tahun 2018. Kondisi mitra selama ini tidak melakukan pembukuan dengan baik, belum bisa mencari harga pokok produk, tidak adanya staf bagian akunting untuk menyusun laporan keuangan. Kondisi mitra saat ini belum pernah menyusun laporan keuangan guna mengetahui harga pokok produk, laba rugi neraca perusahaan dan pelaporan perpajakan kepada negara. Berdasarkan diskusi dengan mitra, tim pelaksana akan memberikan solusi berupa Pelatihan dan Pembuatan Aplikasi Laporan Leuangan Sederhana meliputi "harga pokok produksi, laba rugi, laporan perubahan modal, neraca", dan Pelaporan Pajak Hasil dari kegiatan pengabdian ini adalah: (1) mitra mampu menghitung harga pokok produk (2) mitra mampu membuat laporan keunagan sederhana dan melakukan pendokumentasian bukti transaksi; (3) mitra mampu menghitung, menyusun, membayar dan melaporkan kewajiban perpajakannya dengan benar.
\end{abstract}

\section{Kata Kunci: Laporan Keuangan, Pendampingan, Mandiri}

\section{PENDAHULUAN}

Sentra Ukir Mebel "ThoiFur" dirintis sejak Tahun 2010, mitra beralamat di Mantingan Ngebong Rt 21 Rw 7 Kabupaten Jepara. Sentra Ukir Mebel "ThoiFur"bergerak dalam bidang usaha kecil di bidang produksi ukir mebel. Selama ini mitra menerima pesanan dengan berbagai macam desain ukir sesuai dengan permintaan konsumen. Sampai saat ini mitra menerima pesanan dari dalam kabupaten maupun luar kabupaten Jepara. Untuk memenuhi kebutuhan pesananya mitra mempunyai 6 orang karyawan. Namu dalam hal produksi dan penjualan barang hasil produksi masih menggunakan manajemen tradisional tanpa adanya pembukuan.

Sentra ukir Mebel " Thoifur" ini terkesan tidak teradministrasi dengan baik. Hal ini dikarenakan tidak adanya staf yang focus mengurusi administrasi dari perusahaan tersebut. Disisi lain terdapat keharusan untuk membuat laporan keuangan untuk mengetahui berapa harga pokok produksi sehingga akan di ketahui nilai jual seharusnya, berapa laba yang di terima?, serta bagaimana posisi keuangan perusahaan, semua itu belum di ketahui oleh pemilik usaha dan belum melakukan kewajibanya sebagai warga Negara dalam bidang perpajakan untuk menghitung, membayar serta melaporkan perpajakan.

Aktifitas selama ini berjalan apa adanya tanpa administrasi pembukuan, sehingga yang terjadi perusahaan mengalami kerugian di karnakan belum bisa menghitung harga pokok produksi. Prusahaan juga belum mampu menghitung laba rugi dengan baik sehingga dalam usahanya perusaahaan banyak mempunyai hutang akibat kerugian yang di tanggungnya.Hutang yang di terima adalah hutang perorangan.Bukan dari lembaga keuangan.

Ketidakpahaman pengelola usaha dalam urusan laporan keuangan juga menambah masalah tersendiri dalam usaha ini. Hal ini akan menjadi penghambat dalam proses peminjaman 
dari lembaga perbangkan yang menyebabkan perusahaan sulit berkembang. Selain itu perusahaan juga belum melaksanakan kewajibanya sebagai warga Negara di bidang perpajakan yaitu belum pernah melaporkan perpajakan.Di samping itu pemerintah setempat tidak melakukan pembinanan pada usaha yang belum mempunyai ketertipan administrasi di bidang keuangan.

Beberapa permasalahan mitra yang dapat diselesaikan secara nyata dengan skala prioritas jika dilihat dari analisis situasi diatas adalah sebagai berikut: pertamaPengadministrasian yang kurang baik sehingga tidak ada data dalam penyusun laporan keuangan. KeduaBelum memahami dalam menghitung harga pokok produksi, Sehingga prusahaan tidak mengetahui berapa harga pokok produk yang menyebabkan kerugian. KetigaBelum mampu menyusun laporan keuangan, menghambat pencairan dana dari perbankan. KeempatKetidakpahaman dalam urusan perpajakan menghambat dalam proses pembinaan pemerintah setempat.

Berdasarkan permasalahan mitra diatas, solusi yang di sepakati bersama mitra adalah:

1.1. Penataan manajemen administrasi perusahaan

Tim pengabdian memberikan pelatihan manajemen administrasi dan mendesain sistem aplikasi komputer sederhana berbasis excel untuk mengelola data-data pendapatan, hutang piutang dll. Untuk melengkapi peralatan yang dimiliki mitra tim pengabdian memberikan sebuah printer.

1.2. Mengadakan pelatihan menyusun laporan keuangan dan perpajakan

1.3. Tim pengabdian mengadakan pelatihan menyusun laporan keuangan dan laporan perpajakan yang terdiri dari laporan :

a. laporan harga pokok produksi

b. laporan laba rugi

c. laporan posisi keuangan / neraca

d. laporan keuangan fiskal guna laporan perpajakan

\section{METODE}

Metode yang akan dilakukan untuk mengatasi permasalahan mitra adalah sebagai berikut:

2.1. Melakukan Sosialisasi program kepada mitra

Tim pengusul akan melakukan sosialisasi kepada ketua RT dan RW setempat, serta mitra tentang rencana pengabdian masyarakat.

2.2. Memberikan Aplikasi SIstem Sederhana berbasis Ms. Excel.

Kegiatan pengabdian ini akan mentransfer aplikasi sistem sederhana tentang harga pokok produk, laporan keuangan dan perhitungan pajak. Aplikasi ini menggunakan Ms. Excel agar mudah dipahami dan dilaksanakan oleh mitra.

2.3. Melakukan Pelatihan-Pelatihan yang diperlukan olehMitra

Dalam kegiatan ini tim pengabdani akan melaksanakan pelatihan-pelatihan yang diperlukan oleh mitra, diantaranya adalah:

2.3.1. Pelatihan pembukuan sederhana yaitu pelatihan pembuatan laporan dan laporan keuangan sederhana dengan menggunakan Microsoft Excel.

Kegiatan ini dilaksanakan dengan metode presentasi dan praktik. Pelaksanaan pelatihan pembukuan sederhana dengan menggunakan program Microsoft Excel. Sistem ini akun-akunnya dibuat sederhana sesuai dengan kebutuhan mitra dan tetap mengikuti aturan Standar Akuntansi Keuangan Entitas Tanpa Akuntabilitas Publik (ETAP).

\subsubsection{Pelatihan perhitungan, penyusunan dan pelaporan pajak}

Kegiatan ini dilaksanakan dengan metode presentasi dan praktik. Pelatihan ini dilaksanakan secara manual terlebih dahulu. Setelah mitra memahami dasar perhitungan, penyusunan dan pelaporan pajak secara manual, selanjutnya pelatihan dilanjutkan dengan pelatihan pajak secara elektronik.Pelatihan perpajakan secara elektronik dilaksanakan karena pelaporan pajak saat ini telah menggunakan sistem baru yaitu dengan sistem elektronik dan online.Pelatihan ini 
diupayakan hingga mitra memiliki akun efin yang siap digunakan untuk pelaporan pajak online.

\subsubsection{Melakukan pemantauan keberhasilan program}

Tim pelaksana melakukan pemantauan dan pendampingan dalam penggunaan semua teknologi yang telah ditransfer kepada mitra telah berfungsi dengan optimal yang mencapai target yang telah diharapkan.

Alur kegiatan pengabdian ini dapat ditampilkan dalam gambar berikut:

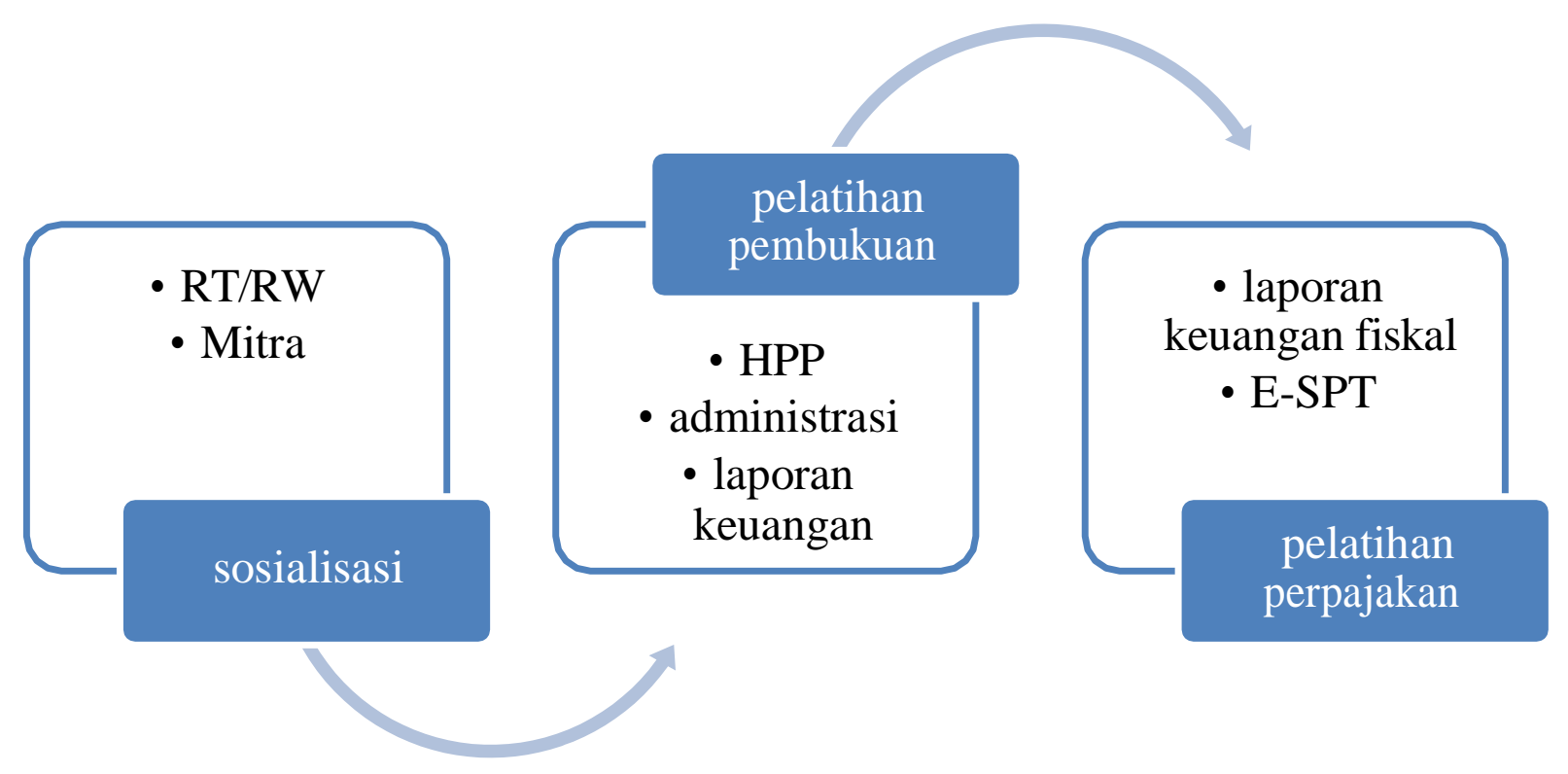

Gambar 1 Alur Kegiatan Pengabdian

\section{HASIL DAN PEMBAHASAN}

Pelatihan ini dilaksanakan pada hari Jum'at tanggal 6 April 2018 mulai pukul 08.00 wib sampai dengan pkl 16.00 wib. Kegiatan ini diikuti oleh 15 orang Adapun materi-matri yang disampaikan sebagai berikut:

3.1. Pembukuan Sederhana

Pelatihan pembukuan sederhana disampaikan oleh Ibu Jumaiyah, S.E., M.Si.Dalam pelatihan ini peserta mula-mula diberikan materi kemudian dilanjutkan dengan praktek penjurnalan menggunakan kasus-kasus riil yang ada di mitra. 


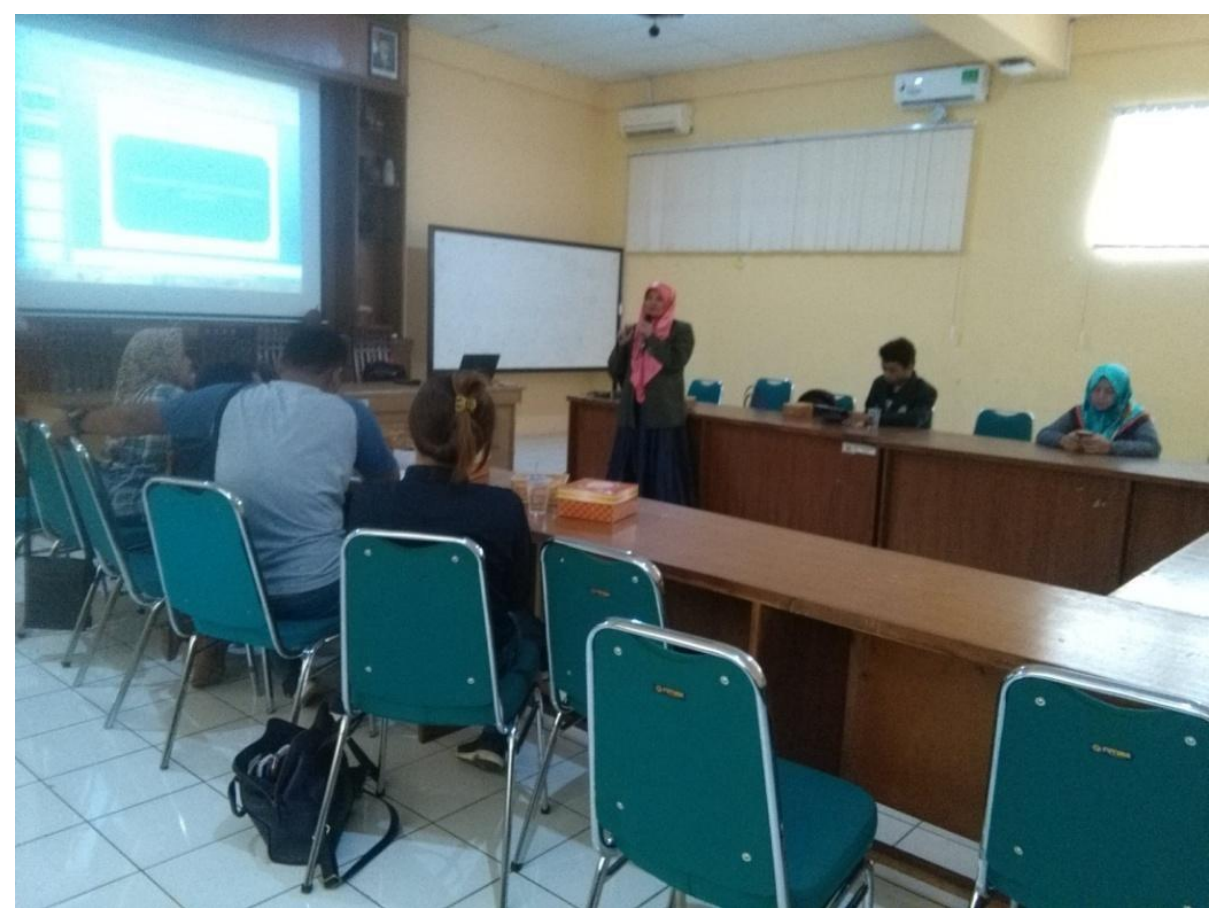

Gambar 2 Pelatihan Sesi Pembukuan Sederhana

\subsection{Perpajakan}

Dalam pelatihan ini disampaikan beberapa materi dasar yang berkaitan dengan kepatuhan pelaksanaan perpajakan sebagai berikut:

3.2.1. Pajak Penghasilan

Materi pajak penghasilan yang disampaikan mengenai:
a. subjek pajak penghasilan
b. objek pajak penghasilan
c. tariff pajak penghasilan
d. cara menghitung, menyusun, membayar dan melaporkan pajak penghasilan

\subsubsection{Pajak Pertambahan Nilai}

Seperti halnya materi pajak penghasilan, dalam materi yang disampaikan mengenai pajak pertambahan nilai adalah:
a. subjek pajak penghasilan,
b. objek pajak penghasilan
c. tarif pajak penghasilan
d. cara menghitung, menyusun, membayar dan melaporkan pajak penghasilan

\subsubsection{Ketentuan Umum Perpajakan (Focus Pada Sanksi dan Denda)}

Ketentuan umum perpajakan yang disampaikan disini lebih focus pada peraturan sanksi dan denda yang akan diberikan oleh Direktorat Jenderal Pajak jika wajib pajak tidak melaksanakan kewajiban perpajakan sesuai dengan aturan yang ada.

Dalam kegiatan pelatihan ini juga diberikan contoh-contoh dan latihan-latihan soal untuk lebih memberikan dalam praktek penghitungan pajak. 


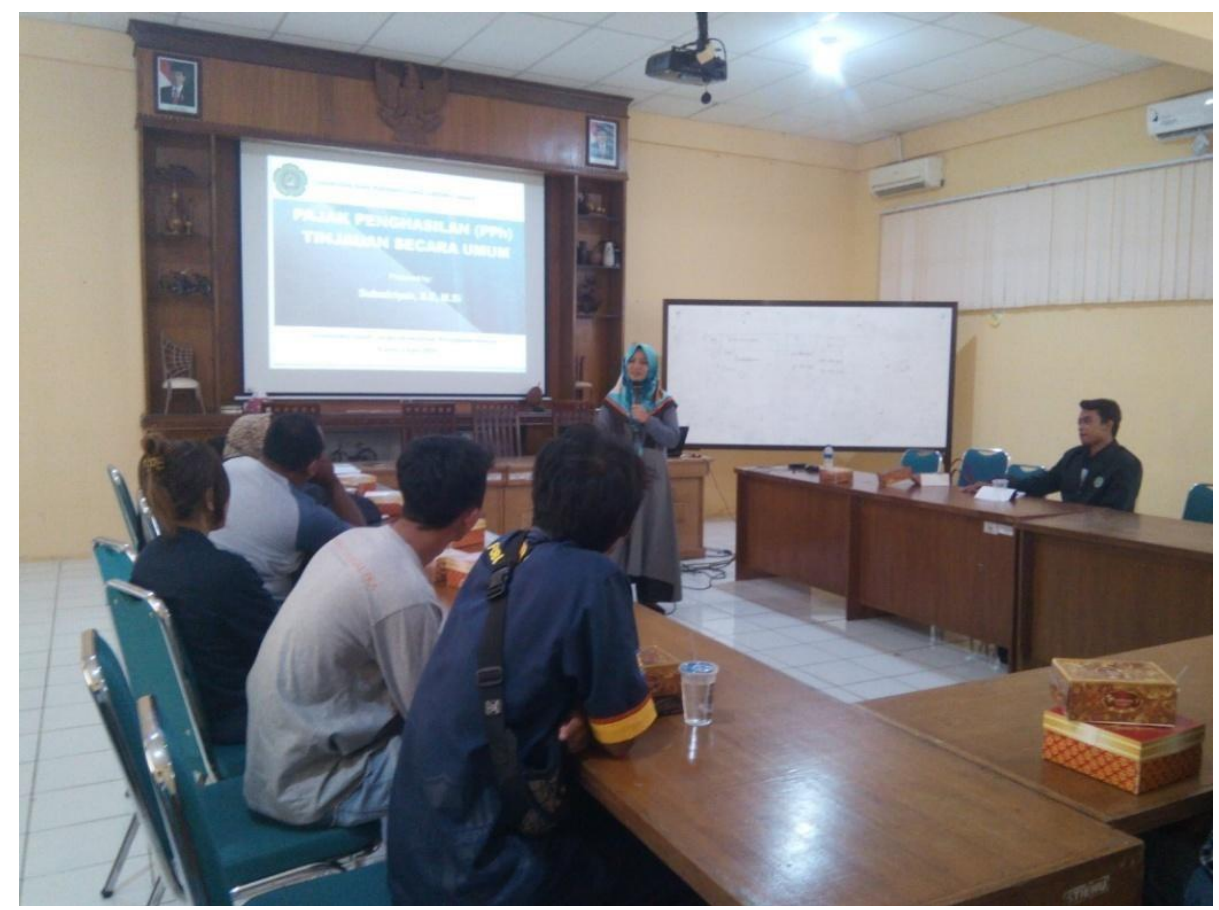

Gambar 3 Pelatihan Sesi Perpajakan

\subsection{Praktek akuntansi}

Selanjutnya, praktek penjurnalan menggunakan Aplikasi diberikan secara langsung kepada peserta. Materi ini di sampaikan oleh dewi Nur maulidiyah. Satu persatu peserta ditunjuk untuk mengelola transaksi. Praktek ini di lakukasan dengan beberapa jenis transaksi sehingga peserta memahami. Praktik ini di teruskan dengan Tanya jawab sekitar kesulitan dan pemecahanya. Berikut ini adalah proses pelatihan dan tanya jawab serta alternatif aplikasi yang digunakan untuk praktek akuntansi.

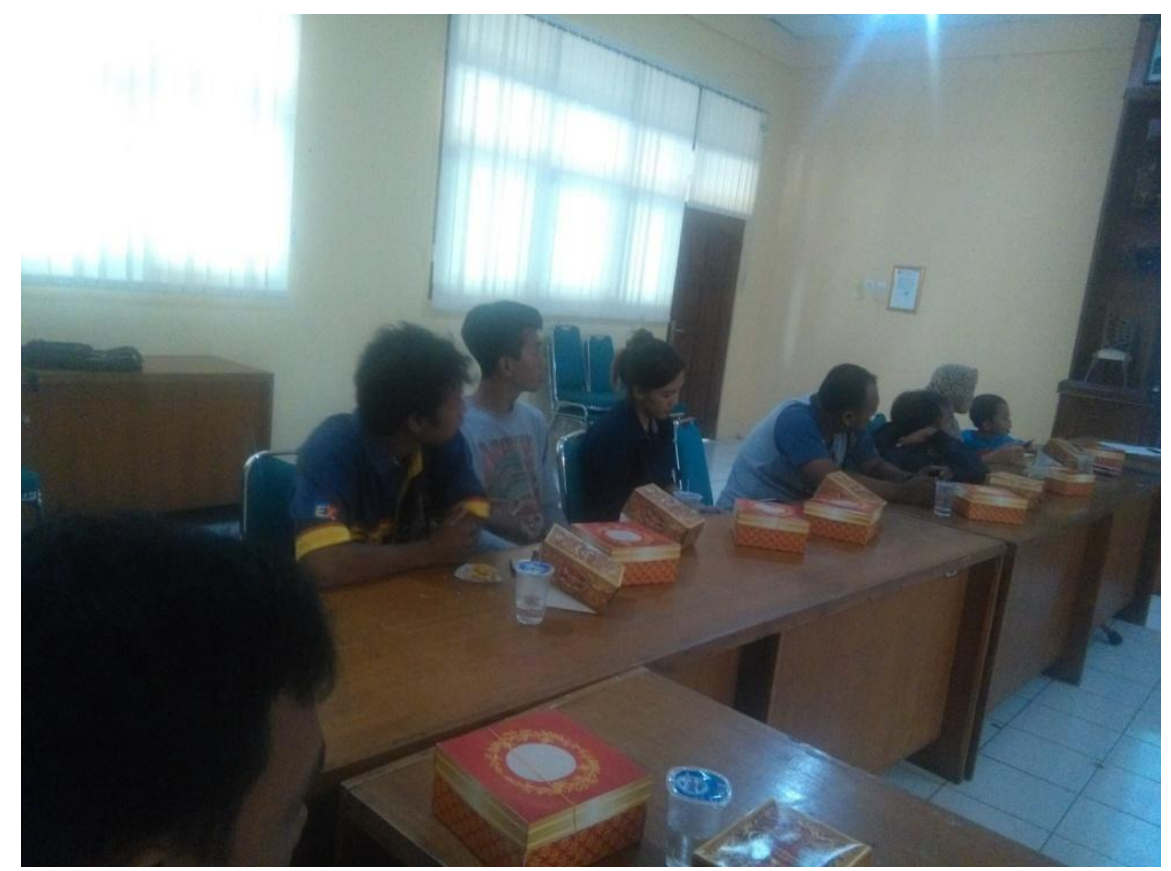

Gambar 4 Pelatihan Sesi Praktek Akuntansi 


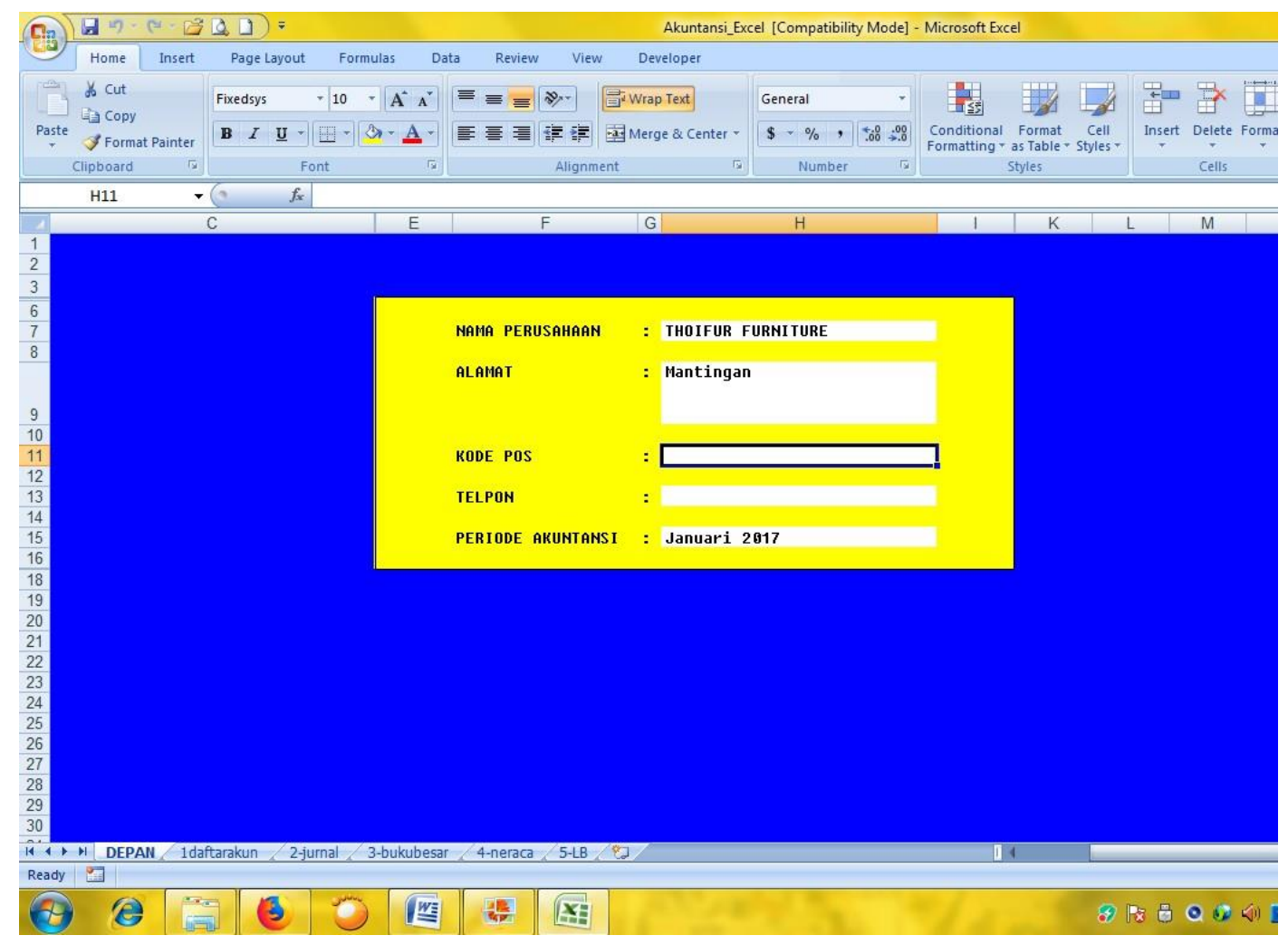

Gambar 5 Alternatif 1 Akuntansi Microsoft Excel

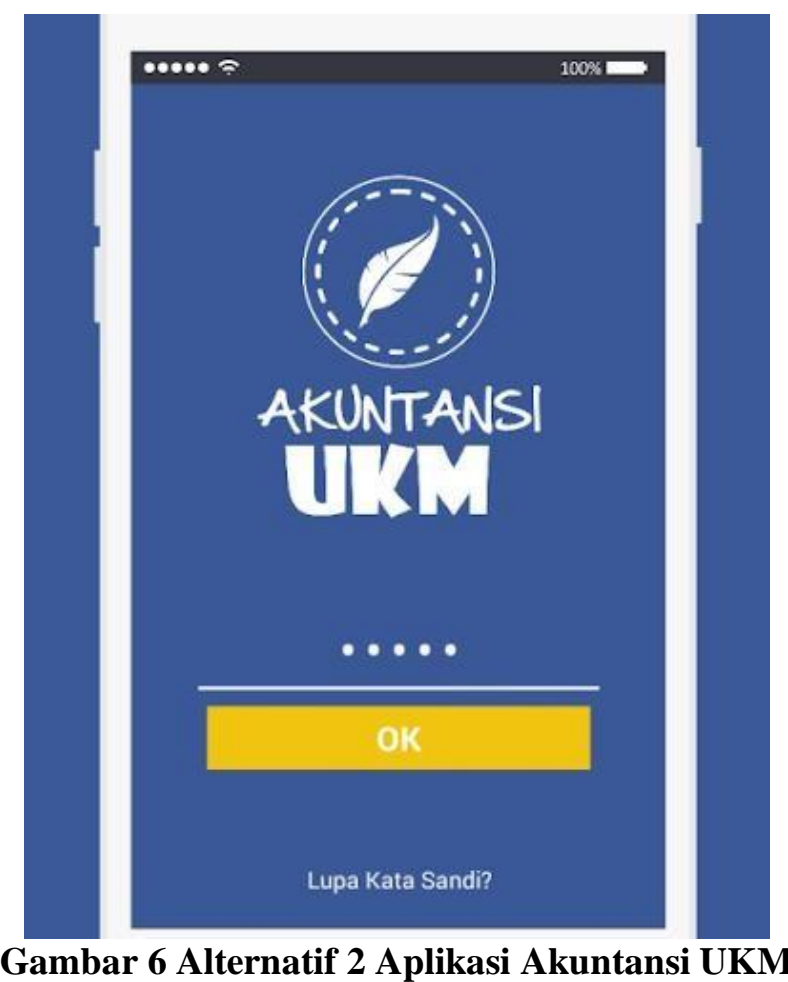

3.4. Pendampingan-Pendampingan

3.4.1. Pendampingan penghitungan, penyusunan dan pelaporan pajak

Pendampingan ini dilakukan pada saat mitra akan menghitung, menyusun, membayar dan melaporkan pajaknya. Dalam kegiatan ini tim abdimas 
memastikan bahwa kewajiban perpajakan mitra telah dilaksanakan dengan tertib dan tepat waktu.

3.4.2. Pendampingan penyusunan dan penyampaian laporan keuangan

Kegiatan ini dilakukan secara berkala dengan komunikasi intensif antara pengabdi dan mitra. Kegiatan pendampingan ini juga dilaksanakan dengan bertemu secara langsung maupun melalui media komunikasi lainnya, yaitu email, pesan singkat (sms), telpon, maupun media lain.

3.4.3. Memberikan sumbangan Sumbangan yang telah di berikan berupa satu buah printer. Sumbangan ini nantinya akan di gunakan oleh mitra untu print out data laporan keuangan.

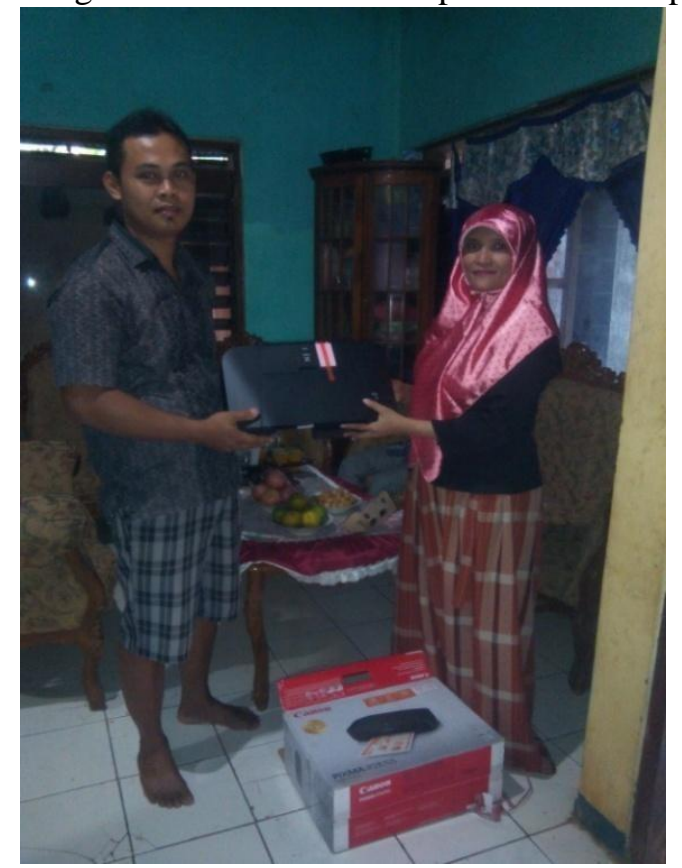

Gambar 7 Serah Terima Printer

\section{KESIMPULAN}

Pemahaman mengenai pembukuan keuangan dan perpajakan penting bagi ThoiFur selaku mitra.Pengabdian ini membantu mitra dalam melakukan kegiatan administrasi secara tertib melalui simple bookkeeping, mitra mampu menyajikan laporan keuangan serta membayar dan melaporkan pajak tertib dan tepat waktu.Selain tentang administrasi, mitra juga mempunyai peralatan berupa printer yang akan memudahkan mitra melakukan pengarsipan dan pelaporan baik laporan keuangan dan perpajakan.

\section{SARAN}

Untuk lebih tertib, sebaiknya kegiatan pendampingan dilanjutkan akhir tahun, untuk memastikan laporan keuangan tahunan tersaji dengan benar, dan laporan perpajakan juga dapat disampaikan tepat waktu.

\section{UCAPAN TERIMAKASIH}

Kami timpengabdian mengucapkan banyak Terimakasih kepadaUniversitas Islam Nahdlatul Ulama Jepara yang mewadahi LPPM UNISNU Jeparadengan segala kegiatan dan pendanaanya. Terimakasih pula kepada LPPM Unisnu Jepara yang telah membimbing tim pengabdian sanmpai dengan selesai dan terbit sebuah artikel pengabdian, kepada tim pengabdian saya ucapkan terimakasih kalian tim yang kompak 


\section{DAFTAR PUSTAKA}

[1] Undang-Undang Republik Indonesia Nomor 20 Tahun 2008 Tentang Usaha Mikro, Kecil, Dan Menengah

[2] Peraturan menteri keuangan republik indonesia nomor 107/pmk.011/2013 tata cara penghitungan, penyetoran, dan pelaporan pajak penghasilan atas penghasilan dari usaha yang diterima atau diperoleh wajib pajak yang memiliki peredaran bruto tertentu

[3] Buku Panduan Pengabdian Reguler Unisnu Jepara TA. 2017 / 2018 